\title{
Response of Soybean and Lentil to a Seed-Row Placed Starter Nitrogen-Phosphorus Fertilizer Blend in a Brown Chernozem in South-Central Saskatchewan
}

\author{
Wasanthika Harshini Galpottage Dona* ${ }^{\circledR}$, Jeff J. Schoenau, Tom King \\ Department of Soil Science, University of Saskatchewan, Saskatoon, Canada \\ Email: ^harshini.gd@usask.ca
}

How to cite this paper: Dona, W.H.G., Schoenau, J.J. and King, T. (2019) Response of Soybean and Lentil to a Seed-Row Placed Starter Nitrogen-Phosphorus Fertilizer Blend in a Brown Chernozem in South-Central Saskatchewan. American Journal of Plant Sciences, 10, 1813-1829.

https://doi.org/10.4236/ajps.2019.1010128

Received: September 10, 2019

Accepted: October 22, 2019

Published: October 25, 2019

Copyright $\odot 2019$ by author(s) and Scientific Research Publishing Inc. This work is licensed under the Creative Commons Attribution International License (CC BY 4.0).

http://creativecommons.org/licenses/by/4.0/

\begin{abstract}
Soybean and lentil are important legume crops in southern Saskatchewan $(\mathrm{SK})$ that can supply the majority of their nitrogen $(\mathrm{N})$ requirement through biological $\mathrm{N}$ fixation (BNF). However, the onset of BNF can be slow in cold; dry prairie soils and a small amount of seed-row placed fertilizer containing both $\mathrm{N}$ and phosphorus (P) may benefit the crop. Nevertheless, high rates of fertilizer in close proximity to the seed can also cause injury. This study was conducted to determine the response of lentil and soybean to a starter N-P fertilizer blend applied in the seed-row. A farm field located at the boundary of the Brown and Dark Brown soil zones in south-central Saskatchewan was selected to evaluate the effect of seed-row placed N-P fertilizer blend: $50 \%$ Urea $+50 \%$ mono-ammonium phosphate (MAP) applied at 0, 10, 20 and 30 $\operatorname{kg~N}$ and $\mathrm{P}_{2} \mathrm{O}_{5} \mathrm{ha}^{-1}$ on emergence, yield, and nutrient uptake. The proportion of nitrogen derived from fixation (ndff) was determined in the soybean using $\mathrm{N}-15$ dilution technique. The rate of $10 \mathrm{~kg} \mathrm{~N}$ and $\mathrm{P}_{2} \mathrm{O}_{5} \mathrm{ha}^{-1}$ was found to be the rate that did not significantly reduce emergence, stand count or proportion of $\mathrm{N}$ derived from fixation, and was sufficient to maximize yield, $\mathrm{N}$ and $\mathrm{P}$ uptake for both soybean and lentil under field conditions. Rates higher than $10 \mathrm{~kg} \mathrm{~N} \mathrm{ha}^{-1}$ in the seed row as starter 28-26-0 blend reduced emergence and decreased the proportion of ndff.
\end{abstract}

\section{Keywords}

Starter Nitrogen-Phosphorus Fertilizers, Seed-Row Fertilizer Placement, Seed Emergence, Seed Injuries, Nitrogen Derived From Fixation 


\section{Introduction}

Soybean and lentils are major legume crops grown in Saskatchewan, with an average yield of $1398 \mathrm{~kg} \cdot \mathrm{ha}^{-1}$ and $1453 \mathrm{~kg} \cdot \mathrm{ha}^{-1}$, respectively [1]. Soybean is well suited to more moist regions of the prairies such as the Dark Brown and Black soil zones in Saskatchewan [2] and is reported to be responsive to starter N in other jurisdictions [3]. Lentil, which is better adapted to drier soil conditions, is mainly grown in southern and west-central portions of the province in the Brown and Dark Brown soil zones [2].

Growers use MAP and urea as major N and P sources in the northern Great Plains of North America, including western Canada [4]. Further, adding fertilizer in the seed-row at planting/seeding is an effective strategy for fertilizer placement, especially to provide a starter source of nutrient for early crop nutrition and growth. Seed-row placement is identified as especially effective for immobile nutrients like $\mathrm{P}$ in cold, prairie soils. This is to ensure the supply of the nutrient early on to the roots of seedlings when it is needed for cell division early in the plant growth cycle [5].

Even though soybean and lentil can supply the majority of their $\mathrm{N}$ requirement through BNF via the Rhizobium symbiosis [6], it takes one to two weeks for nodules to become established. In a controlled environment $\left(24^{\circ} \mathrm{C}\right.$ day, $18^{\circ} \mathrm{C}$ night) study of nitrogenase enzyme activity of soybean (Glycine max var. Kent), nitrogenase activity was nil until 12 days of age of soybean and multiplication of bacteroids per vesicle only began after 20 days [7]. Cooler soil conditions at the time of planting such as occur in northern prairie soils in early spring will further delay biological activities such as atmospheric nitrogen $\left(\mathrm{N}_{2}\right)$ fixation. Starter $\mathrm{N}$ in the seed-row of a legume can help to carry the crop by supplying $\mathrm{N}$ until the nodules get established and begin fixation [3]. Further, fertilization is deemed more important under stress conditions such as when root development is hindered by root disease, as well as when available $\mathrm{N}$ is limited by residue immobilization or any other environmental factors. Therefore, a small amount of starter N-P fertilizer may enhance the early season growth and nutrient uptake that could translate into a final grain yield benefit.

A concern surrounding seed-row placement of fertilizer with crops is that too much fertilizer in close proximity to seed can damage the seedling through desiccation from an osmotic effect. As well many $\mathrm{N}$ fertilizer sources can also cause significant damage through ammonia toxicity. Excessive fertilizer in the seed-row can to serious damage or death of seedlings and reduced stand count. Significant reductions in emergence of soybean in a Saskatchewan soil were observed when rates of $\mathrm{P}$ applied as 11-52-0 fertilizer exceeded $20 \mathrm{~kg} \mathrm{P}_{2} \mathrm{O}_{5} \mathrm{ha}^{-1}$ [8]. Currently, guidelines are available for maximum safe rates of $\mathrm{P}$ applied as MAP and also combinations of MAP with potash for common pulse crops [9]. However, there is no information on the tolerance of soybean and lentil to seed-placed fertilizer blend that contain equal proportions of $\mathrm{N}$ and $\mathrm{P}$ from a MAP and urea fertilizer blend. Therefore, a field study was conducted to assess 
the effect of varying rates of seed placed fertilizer blend: 50\% Urea + 50\% MAP applied at $0,10,20$ and $30 \mathrm{~kg} \mathrm{~N} \mathrm{ha}^{-1}$ on soybean and lentil emergence, grain and straw production, and nutrient uptake. Given the limited information on response of soybean to fertilization under northern prairie conditions, the influence of fertilization on the Ndfa via biological fixation was determined using an ${ }^{15} \mathrm{~N}$ label application to the soybean and use of non-fixing wheat as a reference crop.

\section{Materials and Methods}

\subsection{Site Description}

The field study was initiated on an annually cultivated field located at SE36-20-04-W3 (50.733107N; 106.424019W). This study site was located approximately $7 \mathrm{~km}$ south and $7 \mathrm{~km}$ east of the town of Central Butte, within the Rural Municipality of Enfield, No. 194, Saskatchewan, Canada. The site is located within the Brown soil zone but is very close $(\sim 2 \mathrm{~km})$ to the boundary between the Brown and Dark Brown soil zone. The soils transition from loam to clay loam in texture and are classified as a Brown Chernozem [10]. The soil map unit in which the site is situated describes the site as consisting predominantly of soils of the Haverhill association. Haverhill association can be described as Brown soils that formed in loamy glacial till. It occurs on undulating and undulating dissected landscapes with gentle slopes. Surface texture is commonly described as loam [11]. Prior to the field trial in 2018, wheat (Triticum aestivum) was grown on the site in 2017, and canola in 2016.

\subsection{Initial and Post-Harvest Soil Sampling}

To characterize baseline soil properties at the field trial site, including nutrients before the experiment, pre-seeding composite samples of soil were taken from the $0-15,15-30$ and $30-60 \mathrm{~cm}$ depths on May 2018. Ten soil cores were taken in a transect across the site area with a Dutch auger. Soil samples were placed in a cooler for transport back to Saskatoon and then stored in a refrigerator at $5^{\circ} \mathrm{C}$ until preparation for chemical analysis. Each soil sample collected was air-dried, sieved and the $<2 \mathrm{~mm}$ fraction was retained and analyzed for various extractable nutrients (extractable $\mathrm{P}$, potassium $(\mathrm{K})$, nitrate $\left(\mathrm{NO}_{3}^{-}\right)$- $\mathrm{N}$, sulfate $\left.\left(\mathrm{SO}_{4}^{2-}\right)-\mathrm{S}\right)$ and chemical properties ( $\mathrm{pH}$, electrical conductivity, \% organic carbon) (Table 1).

Post-harvest soil sampling took place in September, 2018. A composite sample was obtained for each plot by collecting two cores within each plot (in-row and between-row) from all treatments and combining the sub-samples according to depth. A hydraulic punch truck fitted with a $5 \mathrm{~cm}$ diameter barrel was used to remove samples at three depth increments $(0-15,15-30$ and $30-60 \mathrm{~cm})$. Samples were placed in a refrigerator at $5^{\circ} \mathrm{C}$ until preparation for chemical analysis, which consisted of air-drying samples at $30^{\circ} \mathrm{C}$ followed by grinding with a Wiley mill to pass a $2 \mathrm{~mm}$ sieve. After processing, the samples were stored at room temperature until chemical analysis. 
Table 1. Summary of baseline soil properties in soil cores collected from the field site locations in spring 2018. Values are means from analysis of ten individual soil cores collected in May across the field site before any treatments or field operations were conducted.

\begin{tabular}{cccccccc}
\hline & \multicolumn{7}{c}{ Soil Property } \\
\cline { 2 - 8 } & $\mathrm{P}^{\dagger}$ & $\mathrm{N}^{\ddagger}$ & $\mathrm{S}^{\S}$ & $\mathrm{K}^{\dagger}$ & $\mathrm{pH}$ & $\mathrm{EC}^{\sharp}$ & $\mathrm{OC}$ \\
\hline$(\mathrm{cm})$ & & $-----\mathrm{mg} \cdot \mathrm{kg} \cdot \mathrm{soil}^{-1}----$ & & & $\left(\mathrm{dS} \cdot \mathrm{m}^{-1}\right)$ & $(\%)$ \\
\hline $0-15$ & 4.9 & 6.0 & 3.4 & 337.1 & 7.7 & 0.2 & 1.6 \\
$15-30$ & - & 4.8 & 4.5 & - & 7.8 & 0.2 & - \\
$30-60$ & - & 3.6 & 7.6 & - & 7.9 & 0.3 & - \\
\hline
\end{tabular}

${ }^{\dagger} \mathrm{P}$ and $\mathrm{K}=$ Modified Kelowna extractable $\mathrm{PO}_{4}-\mathrm{P}$ and $\mathrm{K}$ (Qian et al., 1994). ${ }^{\dagger} \mathrm{N}=\mathrm{CaCl}_{2}$ extractable nitrate, $\mathrm{NO}_{3}-\mathrm{N}$ (Houba et al., 2000). ${ }^{5} \mathrm{~S}=\mathrm{CaCl}_{2}$ extractable sulphate, $\mathrm{SO}_{4}$-S (Houba et al., 2000). ${ }^{\mathrm{p} H} \mathrm{p}$ measured in a 1:2 soil: water suspension (Hendershot et al., 2008). ${ }^{*} \mathrm{EC}$ measured in a 1:2 soil: water suspension (Miller and Curtin, 2008).

\subsection{Experiment Design and Outline of Treatments}

The experiment was set up as a randomized complete block design (RCBD) with four replicates of each treatment. Four rates of starter N: 0, 10, 20 and $30 \mathrm{~kg} \mathrm{~N}$ $\mathrm{ha}^{-1}$ were used in the form of a blend of $50 \%$ urea (46-0-0) and 50\% MAP (11-52-0) with a blend analysis of 28-26-0. In addition to $\mathrm{N}$, this supplied 0,10 , 20 and $30 \mathrm{~kg} \mathrm{P}_{2} \mathrm{O}_{5} \mathrm{ha}^{-1}$. The fertilizer products were obtained from a local agricultural fertilizer retailer (Nutrien Inc). Fertilizer was placed in the seed-row with the lentil and soybean under $\sim 15 \%$ seed bed utilization (opener spread/row spacing) using a seeding tool designed and utilized for seeding small scale field plots. Modern varieties were selected of soybean (Glycine max L. cv. NSC Watson RR2Y), and small red lentil (Lens culinaris L. cv. CDC Maxim). Soybean was selected as the crop for the $\mathrm{N}$ fixation study as there is limited information on how $\mathrm{N}$ fixation in short season soybean responds to starter fertilizer in the prairies. Hard red spring wheat (Triticum aestivum L. cv Brandon) was seeded as the reference crop for soybean $\mathrm{N}$ uptake and BNF.

The area of each plot was $3.0 \mathrm{~m} \times 1.0 \mathrm{~m}$ with 3 seed-rows per plot. Row length was $3.0 \mathrm{~m}$ and row spacing was $25.4 \mathrm{~cm}$ (10 inch spacing) as this is a common spacing configuration for these crops in Saskatchewan. At the first-trifoliate leaf stage of the soybean, a $1 \mathrm{~m} \times 1 \mathrm{~m}$ subplot was established in each of the soybean and reference crop plots. A 10 atom \% excess ${ }^{15} \mathrm{~N}-\left({ }^{15} \mathrm{NH}_{4}\right)\left({ }^{15} \mathrm{NO}_{3}\right)$ fertilizer was uniformly applied to each subplot at the rate of $5 \mathrm{~kg} \mathrm{~N} \mathrm{ha}^{-1}$ in a liquid form dissolved in deionized water.

\subsection{Field Operations}

\subsubsection{Site Preparation}

The whole plot area was lightly rototilled and harrowed to distribute residue and smooth the seed bed. On May 9, 2018, prior to seeding, herbicide was applied for pre-plant control of weeds. Assigned plots for soybean and lentils were sprayed with the liquid herbicide product Vector (540 g.a.i glyphosphate) at $0.8 \mathrm{l} / \mathrm{ac}$ and 
$\mathrm{Aim}^{\circ}$ (carfentrazone) at $0.017 \mathrm{l} / \mathrm{ac}$.

\subsubsection{Seeding}

On the May 22, 2018, prior to seeding, soybean was inoculated with Bradyrhizobium japonicum in peat form (Nodulator ${ }^{\circledR}$ SCG peat-BASF). At the time of seeding, a granular form of this inoculant was also added to the seed row to provide a double inoculation to ensure adequate populations of the B. japonicum in the soil to enable infection and onset of $\mathrm{N}$ fixation in the soybean. The lentils were inoculated with Rhizobium leguminosarum (Nodulator ${ }^{\circledR}$ XL peat-BASF) peat-based inoculant. Seeding operations took place on May 23, 2018, with the date chosen to confirm that soil temperature at the depth of seeding was $10^{\circ} \mathrm{C}$ [2]. Prior to seeding, a packer was run across the plot area to firm the seed bed. The entire study area was seeded with a small plot disk seeder at $25.4 \mathrm{~cm}$ spacing, for a total of three rows within each $3 \mathrm{~m} \times 1 \mathrm{~m}$ plot and at a rate of $79 \mathrm{~kg}$ soybean seeds $\cdot \mathrm{ha}^{-1}$ and $56 \mathrm{~kg}$ lentil seed $\cdot \mathrm{ha}^{-1}$ as per recommended rates [2]. A packer wheeler, attached behind the disk seeder, helped ensure good seed to soil contact. Care was taken to ensure a suitable seeding depth of $2.5 \mathrm{~cm}$, as recommended [12].

\subsubsection{Weed Control}

Application of herbicide after seeding was performed for the first time on June 15, 2018 for weed clean-up with a hand sprayer. Soybean and lentil plots were sprayed with imazamox at $11.7 \mathrm{~g} \cdot \mathrm{ac}^{-1}$ and wheat plots were sprayed with fluroxapyr at $0.125 \mathrm{~L} \cdot \mathrm{ac}^{-1}$ and $2,4-\mathrm{D}$ at $0.340 \mathrm{~L} \cdot \mathrm{ac}^{-1}$.

A second application of herbicides was made on June 27, 2018. Imazamox was applied at $11.7 \mathrm{~g} \cdot \mathrm{ac}^{-1}$ rate with a hand sprayer between the rows of lentils and soybean plots to remove any persisting weeds from the first application, along with some hand hoeing. Fluoxapyr was applied between the rows of the wheat to control weeds.

Fungicide was applied on June 27, 2018 using a field sprayer. Soybean and lentil plots were sprayed with prothioconazole and trifloxystrobin as Delaro at $0.350 \mathrm{~L} \cdot \mathrm{ac}^{-1}$.

\subsubsection{Climate Data}

Climate data (Table 2) was obtained from a weather station located about 500 meters from the field site.

\subsection{5. ${ }^{15} \mathrm{~N}$ Application}

The ${ }^{15} \mathrm{~N}$ application treatments were made on June 20, 2018 for quantifying $\mathrm{N}$ fixation using the ${ }^{15} \mathrm{~N}$ isotope dilution technique for soybean, and hard red spring wheat (Triticum aestivum L. cv Brandon) was used as the non-fixing reference crop [14]. Prior to application of ${ }^{15} \mathrm{~N}$, a stock solution was made by dissolving $58.8 \mathrm{~g}$ of 10 atom\% excess ${ }^{15} \mathrm{~N}-\left({ }^{15} \mathrm{NH}_{4}\right)\left({ }^{15} \mathrm{NO}_{3}\right)$ fertilizer in $400 \mathrm{ml}$ deionized water to provide the desired rate of application in the field of $5 \mathrm{~kg} \mathrm{~N} \mathrm{ha}^{-1}$. When soybean reached the first trifoliate leaf, a $1 \mathrm{~m} \times 1 \mathrm{~m}$ subplot on the north 
Table 2. Comparison of mean monthly precipitation $(\mathrm{mm})$ and temperature $\left({ }^{\circ} \mathrm{C}\right)$ during 2018 growing season at the field site to the 25-year (1992-2017) average.

\begin{tabular}{ccccc}
\hline & \multicolumn{2}{c}{ Mean Monthly Temperature $\left({ }^{\circ} \mathrm{C}\right)$} & Mean Monthly Precipitation $(\mathrm{mm})$ \\
\hline Month & 2018 & HM & 2018 & HM \\
\hline May & 15.0 & 12 & 40.9 & 51 \\
June & 18.3 & 16 & 46.1 & 77 \\
July & 19.3 & 19 & 34.1 & 41 \\
August & 17.8 & 17 & 39.4 & 42 \\
September & 8.1 & 12 & 37.5 & 23 \\
\hline
\end{tabular}

HM = Historical mean (1992-2017) [13].

end of each plot was marked in each of the soybean plots and wheat reference crop plots for application of ${ }^{15} \mathrm{~N}$. A plastic frame was placed on the ground to confine the fertilizer solution within the plot area. For field application of ${ }^{15} \mathrm{~N}, 10$ $\mathrm{ml}$ of the stock solution was dissolved in $4 \mathrm{~L}$ of deionized water for application, followed by another $4 \mathrm{~L}$ of water application over the plot area to rinse off the residual fertilizer contained on the leaves into the soil.

\subsubsection{Crop Harvesting and Processing}

The crops were harvested at physiological maturity. The harvesting operation of lentil and non- ${ }^{15} \mathrm{~N}$ labelled wheat was conducted on August 14, 2018 and soybean $\left({ }^{15} \mathrm{~N}\right.$ applied) and ${ }^{15} \mathrm{~N}$ applied wheat harvesting operations were conducted on September 04, 2018. Two sub-samples of $1 \mathrm{~m}$ length from each plot were hand cut approximately $2.5 \mathrm{~cm}$ above ground. Crop samples from each plot were placed in tagged cloth bags and allowed to air dry for $1-2$ weeks prior to threshing operations.

Soybean, lentil and wheat were threshed, and grain was cleaned in October 2018. Prior to threshing, whole biomass (grain + straw) harvested yields were measured and reported on a $\mathrm{kg} \cdot \mathrm{ha}^{-1}$ basis. Threshing, de-awning and cleaning was accomplished using a Wintersteiger LD 350 thresher. After threshing, the grain was weighed. To obtain above ground straw yield, the grain weight was subtracted from the whole biomass (grain + straw) yields. A sub sample of straw and grain of each crop (soybean, lentil and wheat) was collected in an 8-dram vial. Finally, grain was finely ground using a NutriBullet Balance $e^{\circ}$ grinder/mixer for determination of seed nutrient content by acid digestion.

For ${ }^{15} \mathrm{~N}$ analysis, samples (soybean and ${ }^{15} \mathrm{~N}$ wheat) were further oven-dried over night at $60^{\circ} \mathrm{C}$ to a stable weight, and subsequently ground again to a fine powder using an $8000 \mathrm{D}$ Mixer/Mill ball mill with dual clamps and stored in 8-dram vials for mass spectrometer analysis.

\subsection{Laboratory Analyses}

\subsubsection{Acid Digestion for $\mathrm{N}$ and $\mathrm{P}$ Uptake}

An acid digest of ground grain and straw was conducted [15]. Briefly, $0.25 \mathrm{~g}$ 
$( \pm 0.001 \mathrm{~g})$ of finely ground plant grain or straw was weighed into glass digestion tubes and $5 \mathrm{~mL}$ of concentrated (conc.) sulfuric acid $\left(\mathrm{H}_{2} \mathrm{SO}_{4}\right)$ was added. Samples were placed on a digestion block at $360^{\circ} \mathrm{C}$ for $30 \mathrm{~min}$. Following this, samples were removed from the digestion block, allowed to cool, and $0.5 \mathrm{~mL} \mathrm{H}_{2} \mathrm{O}_{2}$ was added. Samples were then placed on the digestion block an additional three times for $30 \mathrm{~min}$, adding $\mathrm{H}_{2} \mathrm{O}_{2}$ after each heating period. Finally, samples were placed on the digestion block for $1 \mathrm{~h}$. After samples were allowed to cool, distilled water was added to dilute the final volume of the sample to $75 \mathrm{~mL}$ to achieve a final concentration within the detection limit of the instrumentation. Samples were placed in a refrigerator until analysis for $\mathrm{N}$ and $\mathrm{P}$ by Technicon automated colorimetry.

\subsubsection{Plant Available Soil $\mathrm{NO}_{3}^{-}-\mathrm{N}$ and $\mathrm{SO}_{4}^{2-}-\mathrm{S}$}

Plant available soil $\mathrm{NO}_{3}^{-}-\mathrm{N}$ and $\mathrm{SO}_{4}^{2-}-\mathrm{S}$ were extracted according to the methods described in [16]. 20g of air-dried soil was weighed into an extraction bottle and $40 \mathrm{ml}$ of pre-prepared $0.01 \mathrm{M} \mathrm{CaCl}_{2}$ solution $\left(1.11 \mathrm{~g} \mathrm{CaCl}_{2}\right.$ into $1 \mathrm{~L}$ of distilled water) was added into it. The resulting solutions were shaken for $30 \mathrm{~min}$ at 142 RPM on a rotary shaker. After shaking, the suspension was filtered through Whatman No. 42 filter paper into 8-dram vials. Vials were refrigerated until analysis for soil $\mathrm{NO}_{3}^{-}$and $\mathrm{SO}_{4}^{2-}$ by automated colorimetry and plasma emission spectroscopy, respectively.

\subsubsection{Plant Available Soil $P$ and $K$}

The Modified Kelowna extraction procedure [17] was used to extract plant available orthophosphate and potassium $\left(\mathrm{K}^{+}\right)$. In this method, $3 \mathrm{~g}$ of air-dried soil was weighed into an extraction bottle and $30 \mathrm{ml}$ of pre-prepared Kelowna solution $\left(0.25 \mathrm{M}\right.$ acetic acid $\left.+0.015 \mathrm{M} \mathrm{NH}_{4} \mathrm{~F}+0.25 \mathrm{M} \mathrm{NH}_{4} \mathrm{OAc}\right)$ was added into the bottle. Samples were then shaken horizontally on a rotary shaker for $5 \mathrm{~min}$ at 142 RPM. After shaking, samples were filtered through VWR 454 filter paper into $81 / 2$ vials, and the filtrate was stored at $5^{\circ} \mathrm{C}$ until analysis by AA-FE spectrometry for $\mathrm{K}$ and automated colorimetry for $\mathrm{P}$.

\subsection{4. ${ }^{15} \mathrm{~N}$ Analysis}

The finely ground soybean and wheat grain and straw sub-samples were weighed (grains $\sim 2.0 \mathrm{mg}$ and straw $\sim 4.0 \mathrm{mg}$ ) using a Sartorius Microbalance micro-balance and encapsulated using $6 \times 4 \mathrm{~mm}$ tin capsules (Elemental Microanalysis ${ }^{\circ}$ ) into an approximately spherical shape with the air pressed out of the encapsulated sample. The encapsulated grain and straw samples were then analyzed for percent $\mathrm{N}$ and atom $\%{ }^{15} \mathrm{~N}$ using a Costech ECS4010 elemental analyzer coupled to a Delta V Advantage ${ }^{\circ}$ Mass Spectrometer, with a standard for the spectrometry measurement.

\subsection{Calculations}

The nitrogen isotope dilution method provides direct evidence for $\mathrm{N}_{2}$ fixation since the ${ }^{15} \mathrm{~N}$ concentration in the plants exposed to ${ }^{15} \mathrm{~N}_{2}$ is greater than the 
$0.366 \%$ natural abundance but is diluted relative to the non-fixing reference crop if BNF occurs [14]. The isotope dilution method introduced by McAuliffe [18] was used to determine $\mathrm{N}_{2}$ fixed $\left(\mathrm{kg} \cdot \mathrm{ha}^{-1}\right)$ by calculating percentage of $\mathrm{N}$ derived from atmosphere (\%Ndfa) and multiplying by total plant $\mathrm{N}$ calculated for the grain and straw separately:

$$
\text { Amount of } \mathrm{N}_{2} \text { fixed }\left(\mathrm{kg} \cdot \mathrm{ha}^{-1}\right)=\frac{\% \mathrm{Ndfa} \times \text { total } \mathrm{N} \text { in fixing crop }}{100}
$$

Further, Hardarson and Danso [4] described that in the absence of any supply of $\mathrm{N}$ other than soil and ${ }^{15} \mathrm{~N}$-labelled fertilizer, both plants will contain the same ratio of ${ }^{15} \mathrm{~N} /{ }^{14} \mathrm{~N}$, since they are taking $\mathrm{N}$ of similar ${ }^{15} \mathrm{~N} /{ }^{14} \mathrm{~N}$ composition, but not necessarily the same total quantity of $\mathrm{N}$. Therefore, the total amount of $\mathrm{N}$ derived from atmosphere ( $\mathrm{Ndfa}, \mathrm{kg} \mathrm{N} \mathrm{ha}^{-1}$ ) in plant biomass was calculated by $\%$ ${ }^{15} \mathrm{~N}$ atom excess (Ndff) of fixing and non-fixing crop as:

$$
\% \mathrm{Ndfa}=\left(1-\frac{\%{ }^{15} \mathrm{~N} \text { atom excess }}{\%{ }_{\mathrm{F}(\text { fixing crop })}}\right) \times 100
$$

Above equation can be further classified as,

$$
\begin{gathered}
\% \mathrm{Ndff}_{\mathrm{NF}}+\% \mathrm{Ndfs}_{\mathrm{NF}}=100 \\
\% \mathrm{Ndff}_{\mathrm{F}}+\% \mathrm{Ndfs}_{\mathrm{F}}+\% \mathrm{Ndfa}=100 \\
\frac{\% \mathrm{Ndff}_{\mathrm{NF}}}{\% \mathrm{Ndfs}_{\mathrm{NF}}}=\frac{\% \mathrm{Ndff}_{\mathrm{F}}}{\% \mathrm{Ndfs}_{\mathrm{F}}}
\end{gathered}
$$

The total $\mathrm{N}$ in the fixing crop can be obtained by multiplying the dry matter by the $\% \mathrm{~N}$ as;

Total $\mathrm{N}$ in fixingcrop $(\mathrm{kg} / \mathrm{ha})=$ Dry matter of each plant $\times \% \mathrm{~N}$ of each plant

\subsection{Statistical Analysis}

Statistical analyses were conducted using PROC GLIMMIX of SAS, Version 9.4 (SAS Institute Inc, 2017). This study was conducted as an RCBD with a total of four treatments with four replicates. An ANOVA was conducted, with treatments as a fixed effect and block as a random effect. Where applicable, mean comparisons were performed using least significant differences (LSD; equivalent to Fisher's protected LSD) at a significance level of 0.05. PROC UNIVARIATE was used to determine if the measured values of a treatment were normally distributed.

\section{Results}

\subsection{Emergence}

The mean soybean emergence measured at 19 days after seeding (Table 3) shows that at the $20 \mathrm{~kg} \mathrm{~N}, 20 \mathrm{~kg} \mathrm{P}_{2} \mathrm{O}_{5} \mathrm{ha}^{-1}$ seed placed fertilizer rate treatment, the emergence was significantly reduced compared to the $10 \mathrm{~kg} \cdot \mathrm{ha}^{-1}$ and control (no fertilizer treatment) $(\mathrm{P}=0.0270)$. Similarly, above $10 \mathrm{~kg} \cdot \mathrm{ha}^{-1}$, lentil emergence was significantly lower $(\mathrm{P}=0.0272)$. 
Table 3. Mean soybean and lentil plant emergence counts (number of plants emerged in $1 \mathrm{~m}$ row length) at 19 days after seeding in 2018 at Central Butte site.

\begin{tabular}{ccc}
\hline $\begin{array}{c}\text { Fertilizer Rate } \\
\left(\mathrm{kg} \mathrm{N}, \mathrm{P}_{2} \mathrm{O}_{5} \mathrm{ha}^{-1}\right)\end{array}$ & \multicolumn{2}{c}{ 19 Day Emergence Count } \\
\cline { 2 - 3 } 0 & Soybean & Lentil \\
10 & $16^{\mathrm{a} \dagger}$ & $39^{\mathrm{a}}$ \\
20 & $15^{\mathrm{a}}$ & $37^{\mathrm{a}}$ \\
30 & $11^{\mathrm{b}}$ & $23^{\mathrm{b}}$ \\
$\mathrm{SEM}$ & $13^{\mathrm{ab}}$ & $31^{\mathrm{ab}}$ \\
$\mathrm{CV}$ & 1.3125 & 3.6647 \\
$\mathrm{~F}$ value & 24 & 30 \\
$\mathrm{Pr}>\mathrm{F}$ & 4.36 & 3.97 \\
\hline
\end{tabular}

${ }^{\dagger}$ Reported values are the means of four replicates $(n=4)$ of each treatment. Within a column, means followed by the same letter are not significantly different at $\mathrm{P}>0.05$ according to Fisher's protected LSD method. SEM = standard error of mean. CV = Coefficient of variation.

\subsection{Grain and Straw Yield}

Mean soybean and lentil grain and straw yield for the starter N, P fertilizer applied at different rates is shown in Figure 1 and Figure 2, respectively. For soybean yield (Figure 1), there was a trend for fertilization with starter fertilizer to result in higher soybean yield compared to the unfertilized control, with increasing rate resulting in slight decrease in mean grain yield. However, the effect was not statistically significant $(\mathrm{P}=0.3994)$ among the treatments.

For lentil (Figure 2), mean grain and straw yield followed a similar trend to soybean, with slightly higher mean yield at the 10 and $20 \mathrm{~kg} \mathrm{~N}, \mathrm{P}_{2} \mathrm{O}_{5} \mathrm{ha}^{-1}$ rates, and showed decrease with the treatments from 10 to $30 \mathrm{~kg} \cdot \mathrm{ha}^{-1}$. However, even more so than for the soybeans, the yield differences among treatments were small and not statistically significant (for lentil grain and straw, $\mathrm{P}=0.5339$ and $\mathrm{P}$ $=0.1458$, respectively. Overall response to fertilization appeared less in lentil compared to soybean.

\subsection{Grain and Straw Nutrient Uptake}

Mean soybean and lentil $\mathrm{N}$ and $\mathrm{P}$ uptake in grain and straw is shown in Table 4. In soybean, the $\mathrm{N}$ uptake in grain and straw was not significantly increased by $\mathrm{N}$ and $\mathrm{P}$ fertilization $(\mathrm{P}=0.5227)$. There was a trend for about $10 \%-20 \%$ higher mean $\mathrm{N}$ uptake in soybean yield components with fertilization, compared to control (no fertilizer). Increasing fertilizer rate had little evident impact on soybean grain or straw yield. For $\mathrm{P}$ uptake in soybean grain and straw, mean $\mathrm{P}$ uptake in soybean grain for all the rates $\left(10,20,30 \mathrm{~kg} \mathrm{~N}, \mathrm{P}_{2} \mathrm{O}_{5} \mathrm{ha}^{-1}\right)$ was significantly higher $(\mathrm{P}=0.0425)$ than the unfertilized control, but among the fertilizer rates there were no differences. Straw $\mathrm{N}$ and $\mathrm{P}$ uptake by soybean showed a similar pattern to grain $\mathrm{N}$ and $\mathrm{P}$ uptake, but straw $\mathrm{N}$ uptake of fertilized treatments compared to unfertilized control have increased $\mathrm{N}$ uptake by $15 \%-20 \%$. 
In lentils, both $\mathrm{N}$ and $\mathrm{P}$ uptake were quite similar among treatments (Table 4) and there was no significant difference in $\mathrm{N}$ and $\mathrm{P}$ uptake of grain in the different treatments, but a trend to higher $\mathrm{N}$ and $\mathrm{P}$ uptake in the grain. Straw $\mathrm{N}$ uptake was significantly higher in fertilized lentil straw. Compared to $\mathrm{N}$ and $\mathrm{P}$ uptake increases in soybean, the increases in uptake for lentil with fertilization

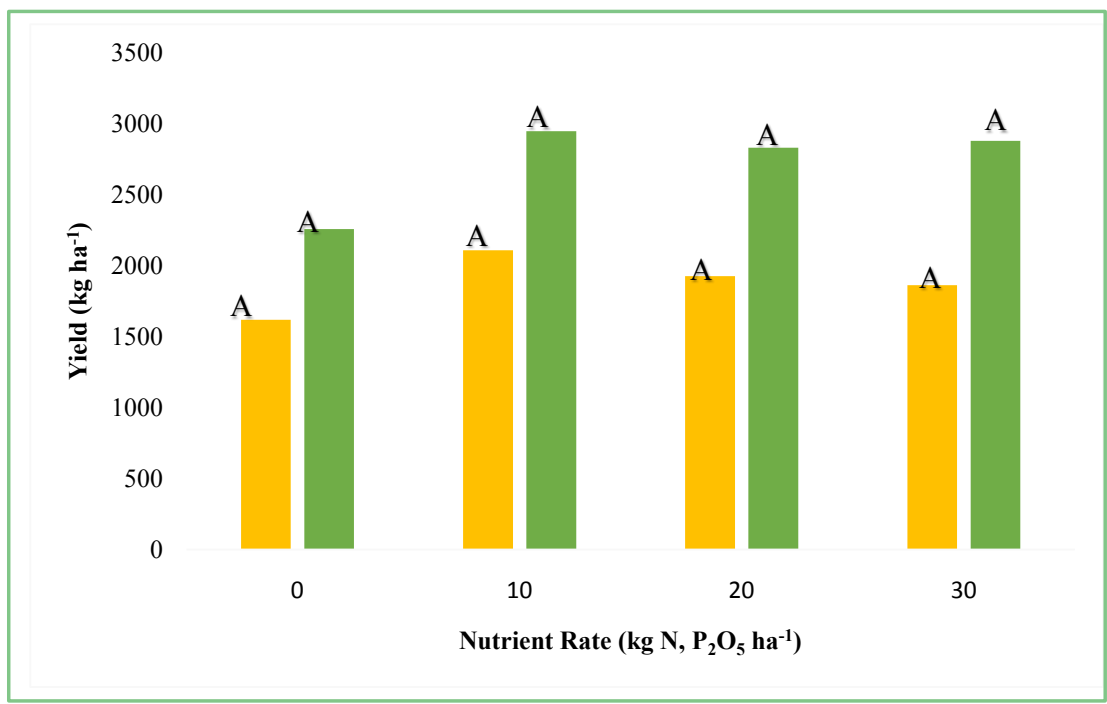

Figure 1. Mean soybean grain (yellow) and straw (green) yield measured in fall 2018 at Central Butte field study site. Fertilizer is blend of 50\% urea and 50\% MAP by weight (analysis: 28-26-0). Reported values are the means of four replicates $(n=4)$ of each treatment. For the same yield component (grain or straw yield), means followed by the same letter are not significantly different at $\mathrm{P}>0.05$. The multi-treatment comparisons were made using Fisher's protected LSD method.

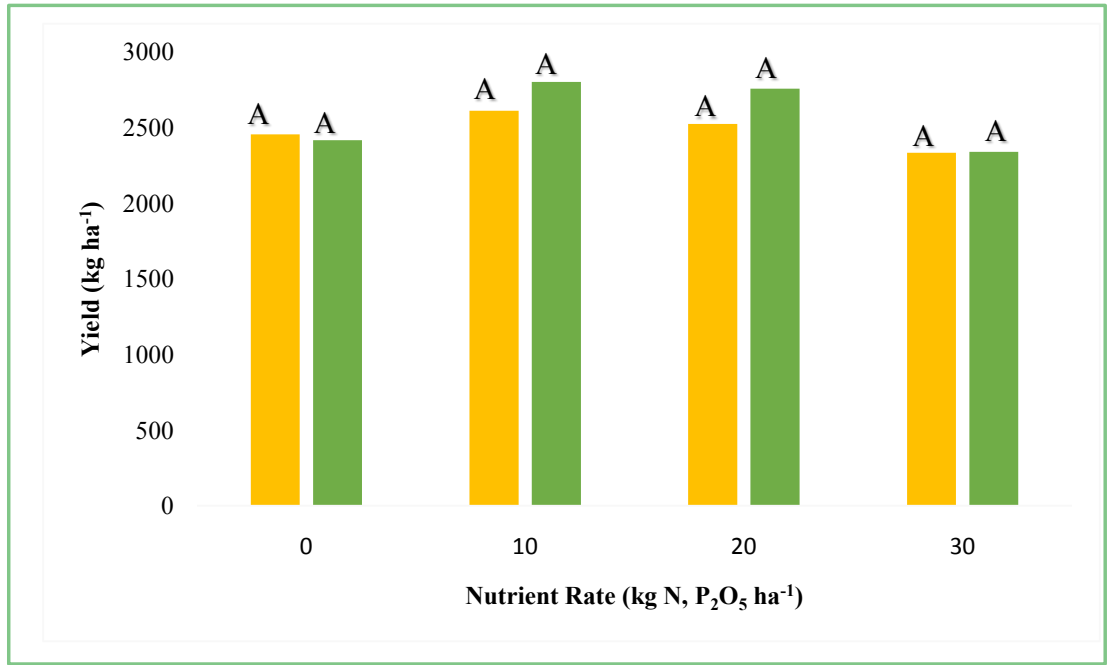

Figure 2. Mean lentil grain (yellow) and straw (green) yield measured in fall 2018. Reported values are the means of four replicates $(n=4)$ of each treatment. Fertilizer is blend of $50 \%$ urea and 50\% MAP by weight (analysis: 28-26-0). For the same yield component (grain or straw yield), means followed by the same letter are not significantly different at $\mathrm{P}>0.05$. The multi-treatment comparisons using Fisher's protected LSD method. 
Table 4. Mean soybean and lentil $\mathrm{N}$ and $\mathrm{P}$ uptake (kg.ha ${ }^{-1}$ uptake in grain and straw) measured in 2018 at Central Butte field study site.

\begin{tabular}{|c|c|c|c|c|c|c|c|c|}
\hline \multirow{3}{*}{$\begin{array}{c}\text { Fertilizer Rate } \\
\left(\mathrm{kg} \mathrm{N}, \mathrm{P}_{2} \mathrm{O}_{5} \mathrm{ha}^{-1}\right)\end{array}$} & \multicolumn{4}{|c|}{ Soybean } & \multicolumn{4}{|c|}{ Lentil } \\
\hline & \multicolumn{2}{|c|}{ Grain } & \multicolumn{2}{|c|}{ Straw } & \multicolumn{2}{|c|}{ Grain } & \multicolumn{2}{|c|}{ Straw } \\
\hline & $\mathrm{N}$ uptake & P uptake & $\mathrm{N}$ uptake & P uptake & $\mathrm{N}$ uptake & P uptake & $\mathrm{N}$ uptake & P uptake \\
\hline & \multicolumn{8}{|c|}{$\mathrm{kg} \cdot \mathrm{ha}^{-1}$} \\
\hline 0 & $70.5^{\mathrm{a} \dagger}$ & $5.7^{\mathrm{b}}$ & $7.9^{\mathrm{a}}$ & $0.9^{\mathrm{b}}$ & $79.8^{\mathrm{a}}$ & $6.2^{\mathrm{a}}$ & $14.1^{\mathrm{b}}$ & $1.6^{\mathrm{a}}$ \\
\hline 10 & $93.0^{\mathrm{a}}$ & $8.8^{\mathrm{a}}$ & $9.9^{\mathrm{a}}$ & $1.2^{\mathrm{ab}}$ & $87.3^{\mathrm{a}}$ & $6.6^{\mathrm{a}}$ & $15.5^{\mathrm{a}}$ & $1.8^{\mathrm{a}}$ \\
\hline 20 & $83.5^{\mathrm{a}}$ & $8.5^{\mathrm{a}}$ & $9.8^{\mathrm{a}}$ & $1.2^{\mathrm{ab}}$ & $83.4^{\mathrm{a}}$ & $6.7^{\mathrm{a}}$ & $16.8^{\mathrm{a}}$ & $1.8^{\mathrm{a}}$ \\
\hline 30 & $80.5^{\mathrm{a}}$ & $8.4^{\mathrm{a}}$ & $10.4^{\mathrm{a}}$ & $1.3^{\mathrm{a}}$ & $77.3^{\mathrm{a}}$ & $6.2^{\mathrm{a}}$ & $14.2^{\mathrm{ab}}$ & $1.7^{\mathrm{a}}$ \\
\hline SEM & 12.3248 & 0.988 & 1.1116 & 0.1312 & 4.3574 & 0.3003 & 0.8421 & 0.1178 \\
\hline F value & 0.79 & 3.83 & 1.09 & 1.77 & 0.89 & 0.75 & 2.21 & 0.84 \\
\hline $\operatorname{Pr}>F$ & 0.5227 & 0.0425 & 0.394 & 0.1952 & 0.4666 & 0.5369 & 0.129 & 0.4909 \\
\hline
\end{tabular}

${ }^{\dagger}$ Reported values are the means of four replicates $(n=4)$ of each treatment. Within a column, means followed by the same letter are not significantly different at $\mathrm{P}>0.05$ according to Fisher's protected LSD method. SEM = standard error of mean.

versus without were smaller, only about $4 \%-7 \%$ increase. Overall, soybeans were more responsive to starter N-P fertilizer in both increased yield and nutrient uptake compared to lentil, especially for $\mathrm{P}$.

\subsection{Nitrogen Fixation}

The mean $\%$ ndfa in soybean grain and straw is provided in Table 5 . The $\%$ ndfa in soybean grain was significantly lower with higher rates of the $\mathrm{N}, \mathrm{P}_{2} \mathrm{O}_{5}$ urea-MAP fertilizer blend added. A reduction in \% ndfa in grain and straw of about $10 \%$ can be observed at the $30 \mathrm{~kg} \mathrm{~N}, \mathrm{P}_{2} \mathrm{O}_{5} \mathrm{ha}^{-1}$ rate compared to the unfertilized control that can be mainly attributed to the effect of the added N. This is expected as $\mathrm{N}$ fertilizer addition at higher rates is known to significantly decrease the proportion of $\mathrm{N}$ in the legume plant derived from biological fixation of atmospheric $\mathrm{N}$.

\section{Discussion}

\subsection{Emergence and Yield}

In this study, the blend of 50\% urea and 50\% MAP giving a product blend analysis of 28-26-0, supplied an available $\mathrm{N}$ to $\mathrm{P}_{2} \mathrm{O}_{5}$ ratio of 1:1. The mean soybean and lentil plant emergence counts at 19 days after seeding (Table 3 ) showed the emergence was reduced by $20 \%-25 \%$ at 20 and $30 \mathrm{~kg} \mathrm{~N}, \mathrm{P}_{2} \mathrm{O}_{5}$ ha $^{-1}$ compared to the $10 \mathrm{~kg} \cdot \mathrm{ha}^{-1}$ and control (no fertilizer) treatment. In a previous controlled environment study by Weiseth [8], MAP was placed in a seed-row with soybean, and only rates above $20 \mathrm{~kg} \mathrm{P}_{2} \mathrm{O}_{5} \mathrm{ha}^{-1}\left(40,60\right.$ and $\left.80 \mathrm{~kg} \mathrm{P}_{2} \mathrm{O}_{5} \mathrm{ha}^{-1}\right)$ showed a significant reduction in emergence using a soil similar to that of the current study. Greater apparent injury per unit of $\mathrm{P}_{2} \mathrm{O}_{5}$ observed in the current study compared 
Table 5. Mean $\mathrm{N}$ derived from atmosphere through biological fixation in soybean grain and straw measured in 2018 field trial at Central Butte.

\begin{tabular}{|c|c|c|}
\hline \multirow{2}{*}{$\begin{array}{l}\text { Fertilizer Rate } \\
\left(\mathrm{kg} \mathrm{N}, \mathrm{P}_{2} \mathrm{O}_{5} \mathrm{ha}^{-1}\right)\end{array}$} & \multicolumn{2}{|c|}{$\begin{array}{c}\mathrm{Ndfa}^{\ddagger} \\
\%\end{array}$} \\
\hline & Grain & Straw \\
\hline 0 & $81.1^{\text {a }}$ & $71.3^{\mathrm{a}}$ \\
\hline 10 & $78.8^{\mathrm{ab}}$ & $60.0^{\mathrm{a}}$ \\
\hline 20 & $71.5^{\mathrm{ab}}$ & $69.1^{\mathrm{a}}$ \\
\hline 30 & $70.9^{\mathrm{b}}$ & $63.7^{\mathrm{a}}$ \\
\hline SEM & 4.2477 & 5.5644 \\
\hline $\mathrm{CV}$ & 26 & 33 \\
\hline F value & 2.72 & 1.21 \\
\hline $\operatorname{Pr}>F$ & 0.0907 & 0.3494 \\
\hline
\end{tabular}

${ }^{\dagger}$ Reported values are the means of four replicates $(n=4)$ of each treatment. Within a column, means followed by the same letter are not significantly different at $\mathrm{P} \leq 0.05$. The multi-treatment comparisons using Fisher's protected LSD method. SEM = standard error of mean. CV = Coefficient of variation. ${ }^{\ddagger} \% \mathrm{Ndfa}$ denotes percentage of $\mathrm{N}$ derived from the atmosphere.

to Weiseth [8] is explained by use of a urea-MAP blend rather than MAP alone and also drier conditions experienced in the field, especially in May and June (Table 2), compared to optimum moisture conditions in a growth chamber. "Fertilizer burn" is related to salt effect of the fertilizer and ammonia/ammonium toxicity [4]. Free $\mathrm{NH}_{3}$ is toxic and can move freely through the cell wall, whereas $\mathrm{NH}_{4}^{+}$cannot, which explains why $\mathrm{N}$ fertilizers that produce large amounts of free ammonia in the vicinity of the granule, like urea, contribute more to germination and seedling damage. Therefore, obviously a blend with urea will cause more damage than MAP alone due to hydrolysis of urea into $\mathrm{NH}_{3}$ and $\mathrm{CO}_{2}$. It is therefore suggested for both soybean and lentil, that as the blend approaches $50 \%$ urea and $50 \% \mathrm{MAP}$, the starter $\mathrm{N}, \mathrm{P}_{2} \mathrm{O}_{5}$ rate is reduced to $10 \mathrm{~kg}$ $\mathrm{N}, \mathrm{P}_{2} \mathrm{O}_{5} \mathrm{ha}^{-1}$.

Low soil moisture and temperature can also adversely impact emergence along with too much fertilizer placed in the seed-row as discussed above. The current recommended minimum average soil temperature at seeding according to Saskatchewan Pulse Growers [2] is $5^{\circ} \mathrm{C}$ and $10^{\circ} \mathrm{C}$ for lentils and soybean, respectively. Mean air temperature at site at the time of seeding was $\sim 15^{\circ} \mathrm{C}$ and this was above the historical mean for the month but the average precipitation was below the average throughout the growing season (from May to August), about 20\% and 4\% lower in May and August, respectively (Table 2). This low moisture condition in spring seeding may also have aggravated the salt and ammonia injury potential of the seed-row fertilizer, particularly for soybean. Low precipitation along with high sand content and low organic matter content in the site will lead to greater concentration of the fertilizer salt in the soil solution, reduced ammonia absorption by water and colloids, and thereby lead to 
more injury at high $\mathrm{N}$ rates for both soybean and lentil. This result agrees with the controlled environment study done using soil from same field.

In 2017, the average grain yield per unit area for soybean in the area the study was conducted was reported as $1398 \mathrm{~kg} \cdot \mathrm{ha}^{-1}$ [1]. The mean soybean grain yield obtained in this field trial in 2018 is higher than the average, with yield of 2003, 1926 , and $1862 \mathrm{~kg} \cdot \mathrm{ha}^{-1}$ for the rates of 10,20 , and $30 \mathrm{~kg} \mathrm{~N}, \mathrm{P}_{2} \mathrm{O}_{5} \mathrm{ha}^{-1}$, respectively. The trend of slight yield reduction with higher rates of seed-row urea-MAP blend may be explained from the emergence reduction and reduced plant stand with the higher rates. The lack of large positive yield responses to fertilization reflects the good ability of the legumes, especially lentil, to access existing $P$ reserves in the soil.

In a meta-analysis of soybean grain yield responses to $\mathrm{N}$ fertilization [19], there was a positive response to fertilizer $\mathrm{N}$ in about half of the published studies, with the average yield increase from $\mathrm{N}$ fertilizer addition in the $\mathrm{N}$-fertilizer responsive studies of $520 \mathrm{~kg} \cdot \mathrm{ha}^{-1}(\mathrm{n}=154)$. The magnitude of the response did not significantly differ among $\mathrm{N}$ rate categories of $0-50,50-100$ and $>100 \mathrm{~kg} \mathrm{~N}$ $\mathrm{ha}^{-1}$. The results of this 2018 field study indicate that $10 \mathrm{~kg} \mathrm{~N}, \mathrm{P}_{2} \mathrm{O}_{5} \mathrm{ha}^{-1}$ as starter seed-row placed urea-MAP blend would be optimal for the soybean in terms of maximizing plant stand and yield on this soil under the conditions of the study. This is supported by the results of Gai [3] that used urea as a starter fertilizer at four different $\mathrm{N}$ rates $\left(0,25,50\right.$ and $\left.75 \mathrm{~kg} \mathrm{~N} \mathrm{ha}^{-1}\right)$, with an average yield soybean yield around $3100 \mathrm{~kg} \cdot \mathrm{ha}^{-1}$ for all the treatments but no significant difference among the treatments.

As for soybean, the mean lentil grain and straw yield was slightly higher in 10 and $20 \mathrm{~kg} \mathrm{~N}, \mathrm{P}_{2} \mathrm{O}_{5} \mathrm{ha}^{-1}$ treatments than control, and yield showed a decrease from 10 to $30 \mathrm{~kg} \mathrm{~N}, \mathrm{P}_{2} \mathrm{O}_{5} \mathrm{ha}^{-1}$, but there was no significant difference among treatments. The mean lentil grain yield in this study: 2610, 2523, and 2334 $\mathrm{kg} \cdot \mathrm{ha}^{-1}$ at the rate of 10,20 and $30 \mathrm{~kg} \mathrm{~N}, \mathrm{P}_{2} \mathrm{O}_{5} \mathrm{ha}^{-1}$, respectively, was higher than the provincial average yield. Slightly lower mean yield with seed-row rates of $\mathrm{N}$, $\mathrm{P}_{2} \mathrm{O}_{5}$ above $10 \mathrm{~kg} \cdot \mathrm{ha}^{-1}$ for lentils observed in this study may be attributed to fertilizer injury reducing emergence and stand count. Therefore, similar to soybean, $10 \mathrm{~kg} \mathrm{~N}, \mathrm{P}_{2} \mathrm{O}_{5} \mathrm{ha}^{-1}$ as seed row placed starter 28-26-0 fertilizer for lentil can be considered best agronomic performer.

\subsection{Crop Nutrition and Biological Nitrogen Fixation}

In soybean, grain $\mathrm{N}$ uptake was not significantly increased by fertilization, but there was a trend for increased $\mathrm{N}$ uptake by about $10 \%-20 \%$ with N, P fertilization, compared to the control (no fertilizer). The $\mathrm{P}$ uptake in soybean grain at all the rates of urea-MAP blend fertilization $\left(10,20,30 \mathrm{~kg} \mathrm{~N}, \mathrm{P}_{2} \mathrm{O}_{5} \mathrm{ha}^{-1}\right)$ was significantly higher $(\mathrm{P}=0.0334)$ than the unfertilized control but among the fertilizer rates the effect was similar. The increase in $\mathrm{P}$ uptake can be explained by the $\mathrm{P}$ in the fertilizer contributing to soil available $\mathrm{P}$ supplies and additional $\mathrm{P}$ uptake by roots that was eventually translocated to the grain. For N, increases in soil available $\mathrm{N}$ from fertilization may be countered by reduced biological nitro- 
gen fixation. The trend in increased $\mathrm{N}$ uptake by soybean with starter $\mathrm{N}, \mathrm{P}_{2} \mathrm{O}_{5}$ fertilization may reflect additional uptake of soil and fertilizer $\mathrm{N}$ without equivalent reduction in $\mathrm{N}$ derived from biological nitrogen fixation, as well as enhancement of $\mathrm{N}$ uptake associated with $\mathrm{P}$ fertilization. There is typically a correlation of nutrient uptake with final crop yield for most plant nutrients [4]. This relationship may exist even for legumes that can fix $\mathrm{N}$ biologically if it is not present in the soil. The linear relationship between soybean grain yield and total $\mathrm{N}$ uptake with above-ground biomass had a slope of $12.7 \mathrm{~kg}$ grain per $\mathrm{kg} \mathrm{N}$ [19]. Further, it was mentioned that on average, a soybean crop yielding $5000 \mathrm{~kg} \cdot \mathrm{ha}^{-1}$ accumulates about $400 \mathrm{~kg} \mathrm{~N} \mathrm{ha}^{-1}$ in its aboveground biomass, and that $\mathrm{N}$ must be provided from indigenous soil resources, the biological fixation process, and/or fertilizer.

In lentils, both $\mathrm{N}$ and $\mathrm{P}$ uptake in yield components were similar among treatments and there was no significant difference in $\mathrm{N}$ and $\mathrm{P}$ uptake in grain and straw in the different treatments. Compared to lentil, soybeans were more responsive to starter N-P fertilizer in increased nutrient uptake, especially for $\mathrm{P}$. Uptake amounts for lentil similar to that obtained in the current study were observed in a study conducted in the Moist Dark Brown soil zone at Scott, SK in 2014 with grain $\mathrm{N}$ and $\mathrm{P}$ uptakes of $90.1 \mathrm{~kg} \mathrm{~N} \mathrm{ha}^{-1}$ and $7.8 \mathrm{~kg} \mathrm{P} \mathrm{ha}^{-1}$, respectively [20]. Corresponding to the lack of large yield response of the soybean and lentil to starter $\mathrm{N}$ and $\mathrm{P}$ fertilization observed at the field site in this thesis, there were also no visual symptoms of $\mathrm{N}$ and $\mathrm{P}$ deficiency in any of the soybean and lentil treatment plots throughout the growing season. In this field study, for both soybean and lentil, highest grain $\mathrm{N}$ and $\mathrm{P}$ uptake was recorded at $10 \mathrm{~kg} \mathrm{~N}, \mathrm{P}_{2} \mathrm{O}_{5} \mathrm{ha}^{-1}$, which had highest grain yield. This is also the fertilizer rate that produced minimal reduction in emergence.

It has been noted by other researchers that little starter $\mathrm{N}$ is typically needed for good pulse yield because they can fix their own $\mathrm{N}$ from the atmosphere in the symbiotic relationship with Rhizobium once they establish nodules, and too much available $\mathrm{N}$ can reduce the contribution from symbiotic fixation [21]. Concomitant with this concept, the \% ndfa in soybean grain (Table 5) was lower with higher rates of $\mathrm{N}$ fertilizer, with about $10 \%$ reduction in the $30 \mathrm{~kg} \mathrm{~N}, \mathrm{P}_{2} \mathrm{O}_{5}$ $\mathrm{ha}^{-1}$ rate compared to the unfertilized control. A similar effect was observed for $\%$ ndfa in straw but was not significantly different among the treatments. In this work, the highest soybean grain $\%$ ndfa with no fertilizer was $81 \%$, with $79 \%, 72 \%$, and $71 \%$ ndfa for 10,20 , and $30 \mathrm{~kg} \mathrm{~N} \mathrm{ha}^{-1}$, respectively. The $\%$ ndfa values reported for soybean in the current study tend to be slightly higher than other studies. However, nodulation of soybean on $0 \mathrm{~N}$ treatment in the field was visually noted to be good. The \% ndfa reported for soybean was $60 \%$ in [22], $57 \%$ in [19] and 50\% in [23] and comparatively lower than the results obtained in this work. Nevertheless, a similar ${ }^{15} \mathrm{~N}$ dilution technique in a Black Chernozmem soil near Rosthern, SK has shown similar results with $74 \%$ ndfa for $\mathrm{N}$ in soybean grain [20]. 
A negative exponential relationship was typically observed between $\mathrm{N}$ fertilizer rate and $\mathrm{N}_{2}$ fixation when $\mathrm{N}$ was applied in the top $0-20 \mathrm{~cm}$ of soil or on the soil surface [19]. The \% ndfa results gained from the field study in this work supports this, as highest \% ndfa was in the unfertilized treatment and lowest in $30 \mathrm{~kg} \mathrm{~N}, \mathrm{P}_{2} \mathrm{O}_{5} \mathrm{ha}^{-1}$. Therefore, the $10 \mathrm{~kg} \mathrm{~N}, \mathrm{P}_{2} \mathrm{O}_{5} \mathrm{ha}^{-1}$ rate of 28-26-0, which gave a \% ndfa that was not significantly different from the control and produced the highest mean yield and $\mathrm{N}$ uptake, may be the best treatment for maximizing yield and contribution of biological fixation from soybean.

\section{Conclusion}

The field study conducted with soybean and lentil in 2018 in south-central Saskatchewan showed a rate of $10 \mathrm{~kg} \mathrm{~N}, \mathrm{P}_{2} \mathrm{O}_{5} \mathrm{ha}^{-1}$ as seed-row placed urea-MAP blend (28-26-0) appeared to be rate that did not significantly reduce emergence, stand count or biological nitrogen fixation and was sufficient to maximize yield, $\mathrm{N}$ and P uptake. The 2018 field site moisture conditions were low compared to the historical mean and overall conditions were very dry. Further, the current field study was conducted over only one season for lentil and soybean. Therefore, expanding field sites and soils would be recommended to encompass and match the environments where the different pulse crops are grown.

\section{Acknowledgements}

This work was supported by the Agriculture Development Fund-Government of Saskatchewan and Saskatchewan Pulse Growers. Further, the authors would like to thank Cory Fatteicher, Ryan Hangs, Gravel Wang, Ranjan Kar for their assistance during the experiments.

\section{Conflicts of Interest}

The authors declare no conflicts of interest regarding the publication of this paper.

\section{References}

[1] Government of Saskatchewan (2017) 2017 Specialty Crop Report. Saskatoon, Saskatchewan.

[2] Saskatchewan Pulse Growers (2018) Saskatchewan Pulse Crops ;Seeding and Variety Guide 2018. Saskatoon, Saskatchewan.

[3] Gai, Z., Zhang, J. and Li., C. (2017) Effects of Starter Nitrogen Fertilizer on Soybean Root Activity, Leaf Photosynthesis and Grain Yield. PLoS ONE, 12, e0174841. https://doi.org/10.1371/journal.pone.0174841

[4] Havlin, J.L., Beaton, J.D., Tisdale, S.L. and Nelson, W.L. (2014) Soil Fertility and Fertilizers; An Introduction to Nutrient Management. 6th Edition, Prentice Hall, Upper Saddle River, NJ.

[5] Grant, C. (2012) Phosphorus Management for Sensitive Crops: Managing Phosphorus through the Rotation. Proceedings of 2012 Manitoba Agronomists Conference, Winnipeg, $\mathrm{MB}$. 
[6] Atkins, C.A. (1987) Metabolism and Translocation of Fixed Nitrogen in the Nodulated Legume. Plant and Soil , 100, 157-169. https://doi.org/10.1007/BF02370939

[7] Hardy, R.W.F., Burns, R.C., Hebert, R.R., Holsten, R.D. and Jackson, E.K. (1971) Biological Nitrogen Fixation: A Key to World Protein. Plant Soil, 35, 561-590. https://doi.org/10.1007/BF02661879

[8] Weiseth, B. (2015) Impact of Fertilizer Placement on Phosphorus in Crop, Soil, and Run-off Water in a Brown Chernozem in South-Central Saskatchewan. University of Saskatchewn, Saskatoon.

[9] Schoenau, J.J., Qian, P. and King, T. (2007) Strategies for Improving the Efficiency and Crop Safety of Starter Fertilizer Phosphorus and Potassium. Agriculture Development Fund Project 20050725 Final Report.

[10] Soil Classification Working Group (1998) The Canadian System of Soil Classification. Agriculture and Agri-Food Canada Publication, Ottawa.

[11] Saskatchewan Soil Survey (1993) The Soils of St. Andrews; Rural Municipality No. 287 Saskatchewan.

[12] Barker, B. (2016) Seeding Soybeans 101. Saskatchewan pulse Growers.

[13] Environment and Climate Change Canada (2018) Historical Climate Data. http://climate.weather.gc.ca/historical_data/search_historic_data_e.html

[14] Hardarson, G. and Danso, S.K.A. (1990) Use of ${ }^{15} \mathrm{~N}$ Methodology to Assess Biological Nitrogen Fixation. In: Hardanson, G., Ed., Use of Nuclear Techniques in Studies of Soil-Plant Relationships, International Atomic Energy Agency, Vienna, 129-160.

[15] Thomas, R.L., Sheard, R.W. and Moyer, J.R. (1967) Comparison of Conventional and Automated Procedures for Nitrogen, Phosphorus, and Potassium Analysis of Plant Material Using a Single Digestion. Agronomy Journal, 59, 240-243. https://doi.org/10.2134/agronj1967.00021962005900030010x

[16] Houba, V.J.G., Temminghoff, E.J.M., Gaikhorst, G.A. and Van Vark, W. (2000) Soil Analysis Procedures Using 0.01 M Calcium Chloride as Extraction Reagent. Communications in Soil Science and Plant Analysis, 31, 1299-1396.

https://doi.org/10.1080/00103620009370514

[17] Qian, P., Schoenau, J.J. and Karamanos, R.E. (1994) Simultaneous Extraction of Available Phosphorus and Potassium with a New Soil Test: A Modification of Kelowna Extraction. Communications in Soil Science and Plant Analysis, 25, 627-635. https://doi.org/10.1080/00103629409369068

[18] McAuliffe, C., Chamblee, D.S., Uribe-Arango, H. and Woodhouse, W.W. (1958) Influence of Inorganic Nitrogen on Nitrogen Fixation by Legumes as Revealed by ${ }^{15} \mathrm{~N}$. Agronomy Journal, 50, 334-337. https://doi.org/10.2134/agronj1958.00021962005000060014x

[19] Salvagiotti, F., Cassman, K.G., Specht, J.E., Walters, D.T., Weiss, A. and Dobermann, A. (2008) Nitrogen Uptake, Fixation and Response to fertilizer N in Soybeans : A Review. Field Crops Research, 108, 1-13. https://doi.org/10.1016/j.fcr.2008.03.001

[20] Xie, J., Schoenau, J. and Warkentin, T.D. (2018) Yield and Uptake of Nitrogen and Phosphorus in Soybean, Pea, and Lentil and Effects on Soil Nutrient Supply and Crop Yield in the Succeeding Year in Saskatchewan. Canadian Journal of Plant Science, 98, 5-16. https://doi.org/10.1139/CJPS-2016-0342

[21] Yang, J.Y., Drury, C.F., Yang, X.M., Jong, R. De, Huffman, E.C., Campbell, C.A. and Kirkwood, V. (2010) Agriculture, Ecosystems and Environment Estimating Biological $\mathrm{N}_{2}$ Fixation in Canadian Agricultural Land Using Legume Yields. Agriculture, 
Ecosystems \& Environment, 137, 192-201.

https://doi.org/10.1016/j.agee.2010.02.004

[22] Herridge, D.F., Peoples, M.B. and Boddey, R.M. (2008) Global Inputs of Biological Nitrogen Fixation in Agricultural Systems. Plant Soil, 311, 1-18.

https://doi.org/10.1007/s11104-008-9668-3

[23] Peoples, M.B., Brockwell, J., Herridge, D.F., Rochester, I.J., Alves, B.J.R., Urquiaga, S., Boddey, R.M., Dakora, F.D., Bhattarai, S., Maskey, S.L., Sampet, C., Rerkasem, B., Khan, D.F., Hauggaard-Nielsen, H. and Jensen, E.S. (2009) The Contributions of Nitrogen-Fixing Crop Legumes to the Productivity of Agricultural Systems. Symbiosis, 48, 1-17. https://doi.org/10.1007/BF03179980 